\title{
TOTAL BAKTERI DAN IDENTIFIKASI Escherichia coli PADA JAJANAN SIOMAY IKAN YANG DIJAJAKAN DI BEBERAPA SD NEGERI DI KOTA KENDARI
}

Total Bacteria and Identification of Escherichia coli on Siomay Fish Sold In Several Elementary School In Kendari City

\author{
Wa Ode Rusmianur, Asnani, Suwarjoyowirayatno \\ Jurusan Teknologi Hasil Perikanan, Fakultas Perikanan dan IImu Kelautan Universitas Halu Oleo, Kendari, \\ Sulawesi Tenggara, Indonesia
}

*Email korespondensi: waoderusmianur98@gmail.com (Telp: +6282293496697)

Diterima: 20 September/ Disetujui 10 Oktober 2019

Cara sitasi: Rusmianur WO, Asnani, Suwarjoyowirayatno. 2019. Total bakteri dan identifikasi Escherichia coli pada jajanan siomay ikan yang dijajakan dibeberapa SD Negeri di Kota Kendari. Jurnal Fish Protech. 2(2):196-201.

\begin{abstract}
Contamination in food may cause foodborne disease, one of them are diarrhea and food poisoning. The cause of contamination in food is microbial contamination. This study aims to determine the presence of contamination Escherichia coli and the number of bacteria on fish siomay, being sold at public elementary school in Kendari city (Kendari barat, Mandonga, Puwatu and Poasia). This Research used a descriptive survey with random sampling method to determine the number of bacteria and Escherichia coli using total plate count (TPC) and EMBA medium. The results showed that the

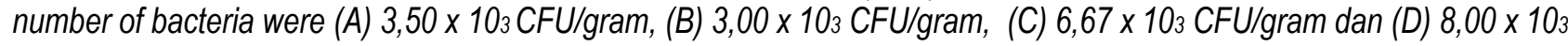
CFU/gram and wasfound Escherichia coli in samples $A, C$ and $D$, while samples $B$ not found Escherichia coli. This research showed that 3 out of 4 siomay fish samples (80\%) contain Escherichia coli and the number of bacteria still according to SNI standar and siomay is still suitable for consumption.
\end{abstract}

Keywords: Escherichia coli. Foodborne disease, Siomay, Total Plate Count (TPC).

\begin{abstract}
ABSTRAK
Adanya kontaminasi pada pangan jajanan dapat menyebabkan foodborne disease, salah satunya adalah diare dan keracunan pangan. Penyebab kontaminasi pada pangan adalah cemaran mikroba. Penelitian ini bertujuan untuk mengetahui adanya cemaran Escherichia coli dan jumlah bakteri pada jajanan siomay ikan yang dijajakan di Beberapa Sekolah Dasar Negeri di Kota Kendari (kecamatan Kendari barat, Mandonga, Puwatu dan Poasia). Metode penelitian yaitu Survey deskriptif dengan pengambilan sampel secara acak (random sampling) untuk mengetahui jumlah bakteri dan adanya bakteri Escherichia coli pada makanan jajanan siomay ikan dengan menggunakan metode TPC dan isolasi pada media EMBA. Hasil Penelitian menunjukan rata-rata jumlah bakteri yaitu (A) $3,50 \times 10_{3} \mathrm{CFU} / \mathrm{gram},(B) 3,00 \times 10_{3}$ CFU/gram, (C) 6,67 x 103 CFU/gram dan (D) 8,00 x CFU/gram ditemukan Escherichia coli pada sampel A, C dan D sedangkan sampel B tidak ditemukan bakteri Escherichia coli. Hal iniMenunjukkan bahwa 3 dari 4 sampel siomay telah tercemar bakteri Escherichia coli sebesar 80\% dengan total koloni bakteri masih memenuhi syarat yang ditetapkan SNI siomay ikan dan masih layak dikonsumsi.
\end{abstract}

Kata kunci: Escherichia coli, Foodborne disease, Siomay, Total Plate Count (TPC).

\section{PENDAHULUAN}

Siomay merupakan salah satu jenis jajanan yang banyak digemari masyarakat baik dari kalangan anakanak hingga dewasa, siomay banyak ditemukan di beberapa sekolah dan hampir semua sekolah dasar memiliki pedagang khusus berupa pedagang siomay ikan. Siswa sekolah dasar merupakan salah satu konsumen terbesar bagi para pedagang siomay, dikarenakan siswa sekolah dasar belum mengetahui pengaruh dari kurangnya higienitas makanan, bahaya dari makanan yang kurang bersih, serta ketidaktahuan 
akan dampak jajanan bagi kesehatan. Siomay biasanya dibuat dari daging olahan baik dari daging ayam, ikan, udang, cumi, dan lain-lain.

Menurut BPOM RI Direktorat Inspeksi dan Sertifikasi Pangan bersama 26 Balai POM di seluruh Indonesia pada tahun 2007 melakukan pengawasan terhadap Pangan Jajanan Anak Sekolah (PJAS) dan menunjukkan hasil bahwa 45\% PJAS tidak memenuhi syarat karena mengandung bahan kimia berbahaya dan akibat cemaran mikrobiologi.

Berdasarkan data Dinas Kesehatan Provinsi Sulawesi tenggara pada tahun 2014 jumlah kasus diare yang ditangani sebanyak 42.293 kasus $(81,90 \%$ dari perkiraan kasus). Pada tahun 2015 menurun sebanyak 41.071 kasus $(77,74 \%$ dari perkiraan kasus). Pada tahun 2016 menurun sebanyak 35.864 kasus atau (46,77\% dari perkiraan kasus). Data Dinas Kesehatan Kota Kendari menunjukkan prevalensi kasus diare di Kota Kendari pada tahun 2015 sebanyak 7.436 kasus. Meningkat pada tahun 2016 sebanyak 7.691 kasus dan pada tahun 2017 menurun sebanyak 6.430 kasus.

Berdasarkan data World Health Organization (WHO) menunjukkan terdapat 1500 juta kejadian penyakit bawaan makanan dengan jumlah penderita meninggal sebanyak 3 juta. Menurut WHO, Afrika adalah negara yang mempunyai penyakit bawaan makanan (foodborne disease) terbanyak disusul oleh Asia Tenggara. Foodborne disease dapat disebabkan oleh berbagai macam mikroba, antara lain Esceherichia coli, Salmonella sp., Bacillus anthracis, Shigella sp., Vibrio sp., Campylobacter sp., Listeria monocytogenes, dan Clostridium sp. selain karena cemaran mikroba dapat juga disebabkan bahan kimia berbahaya seperti toksin alami, peptisida, logam berat, dan lain-lain.

Berdasarkan penelitian Tangahu (2014) melakukan penelitian pada 3 sampel siomay di Kota Gorontalo, hasil yang diperoleh bahwa 3 sampel tersebut telah tercemar oleh bakteri tetapi masih layak konsumsi karena jumlah koloni tidak melebihi ambang batas dengan total tiap sampel adalah $\mathrm{A} 3 \times 10{ }_{3} \mathrm{CFU} / \mathrm{g}$, B $1,7 \times 102 \mathrm{CFU} / \mathrm{g}$, dan C $4 \times 10{ }_{3} \mathrm{CFU} / \mathrm{g}$.

Berbeda dengan penelitian yang dilakukan oleh Apriliana (2007) yang meneliti 9 sampel produk jajanan kali lima di SD Kecamatan Wonosari diperoleh hasil bahwa dari 9 sampel yang diteliti yang paling berpotensi menyebabkan keracunan adalah sampel Siomay dengan total bakteri pada kisaran $1,1 \times 10_{6}$ $1,3 \times 10_{8} \mathrm{CFU} / \mathrm{gram}$. Dengan kondisi seperti ini dapat dinyatakan bahwa Siomay tidak layak untuk dikonsumsi karena jumlah bakteri telah melebihi ambang batas.

Berdasarkan uraian diatas perlu dilakukan suatu penelitian tentang Total bakteri dan identifikasi bakteri Escherichia coli pada Siomay ikan yang dijajakan di beberapa SD Negeri di Kota Kendari.

\section{Alat dan Bahan}

\section{METODE PENELITIAN}

Bahan utama yang digunakan pada penelitian analisis total bakteri pada jajanan siomay yang dijual dibeberapa sekolah kota kendari berupa siomay ikan yang diperoleh langsung dari penjual yang berada di beberapa sekolah, sedangkan bahan-bahan pendukung penelitian yaitu Plate Count Agar (PCA)/Nutrient Agar (merck), Natrium Clorida ( $\mathrm{NaCl}$ ), media BFP/Butterfield phosphate (merck), Eosin Methylen Blue Agar/EMB (oxoid) dan aquadest.

Alat yang digunakan pada penelitian ini antara lain: blender, Autoclave (All American No.75X), Laminar (Air Flow OMRON H3BA), incubator (Memmert Modell 200), Hotplate (Cimarec), Brand Micropipette (dragon), lemari pendingin, jarum ose, spritus, gelas beker $(250 \mathrm{~mL}$ dan $500 \mathrm{~mL}$ ) (duran), tabung erlenmeyer (250 ml dan $500 \mathrm{ml}$ ) (Iwaky Pyrex), tabung ukur (100 ml dan $10 \mathrm{ml})$ (Pyrex grade A), tabung reaksi (duran), rak tabung (manufaktur), cawan petri (Normax), lampu Bunsen (local), pipet, tip (1000 $\mu$ dan $100 \mu$ ) (Scilogex), oven (Memmert), timbangan, tisu, kapas, handscoon, masker, serta kertas label. 


\section{Populasi dan Sampel Penelitian}

Populasi penelitian yang dimaksud dalam penelitian ini berupa Penjual siomay yang berada di SD negeri di kecamatan Kendari barat (Kandai), Mandonga, Puwatu dan Poasia.

Sampel berupa siomay yang diambil dari beberapa SD Negeri di Kecamatan Kendari barat (Kandai), Mandonga, Puwatu dan Poasia. Pengambilan sampel di beberapa Kecamatan yang berbeda merupakan perwakilan dari sekolah dasar di kota kendari yang ada. Masing-masing Sampel siomay diambil sebanyak 25 gram dan disimpan dalam plastik steril kemudian dimasukan kedalam box berisi es. Sampel dihaluskan menggunakan stomacher kemudian dilakukan pengenceran dalam media cair BFP dengan konsentrasi 10-1, 10-2, 10-3, 10-4, 10-510. $6,10-7$

\section{Sterilisasi Alat dan Bahan}

\section{Sterilisasi basah}

Bahan dan alat yang di sterilisasi dalam autoklaf yaitu media PCA, EMB, BFP, akuades dalam tabung Erlenmeyer dan tabung reaksi, dan tip. Bahan dan alat baik yang belum digunakan dan sudah digunakan terlebih dahulu dibungkus dengan plastik tahan panas, lalu dimasukkan kedalam autoklaf selama \pm 1 -2 jam

\section{Sterilisasi kering}

Bahan dan alat yang di sterilisasi dalam oven seperti cawan petri, spatula dan pinset. Sebelum dimasukan ke dalam oven telah dibungkus dengan kertas. Kemudian masukkan kedalam oven \pm 1 jam hingga mencapai suhu $150^{\circ} \mathrm{C}$.

\section{Tahap Pengambilan Sampel dan persiapan sampel}

Metode penelitian ini adalah survey deskriptif dengan pengambilan sampel secara acak (random sampling) untuk mengetahui keberadaan bakteri pada beberapa produk siomay ikan di beberapa SD Negeri di Kecamatan (Kota lama/Kendari barat, Mandonga, Puwatu dan Poasia) kota Kendari, sampel diambil sebanyak 25 gram dari masing-masing siomay sebelum digoreng. Dari keempat Kecamatan yang diambil sampel siomay ikan, telah dapat dikatakan mewakili sebagian besar Sekolah dasar yang ada di
Kota Kendari dan diberi kode sampel $A$, sampel $B$, sampel $C$ dan sampel $D$, kemudian dimasukkan ke dalam plastik, sampel dibeli kisaran pukul 09.00-12.00 WIB. Kemudian sampel yang telah dibeli disimpan dalam freezer dengan suhu $0-3^{\circ} \mathrm{C}$, sehingga kondisi sampel tidak mengalami perubahan. Ketika sampel akan digunakan, sebelumnya terlebih dahulu diblender sampai halus dan encer, lalu ditimbang dengan ukuran 25 gram.

\section{Variabel pengamatan}

Variabel pengamatan pada penelitian ini terdiri dari Uji TPC (menggunakan media PCA/Plate Count Agar) dan Uji Escherichia coli (menggunakan media EMB) untuk mengetahui jenis bakteri tersebut

\section{Uji TPC/ALT (SNI 01-2332.3-2006)}

Uji TPC ini dimulai dari pengenceran bahan yang dijadikan sampel, kemudian dihomogenisasi dengan (BFP) dengan pengenceran 10-1 sampai dengan pengenceran 10-7 dan hasil pengenceran diinokulasi dalam media PCA/Plate Count Agar dengan menggunakan metode spread plate lalu diinkubasi dalam suhu $37^{\circ} \mathrm{C}$ selama 24 jam. Setelah diinkubasi dan bakteri yang tumbuh akan dihitung jumlah koloni yang terbentuk dengan menggunakan colony counter atau menghitung secara manual dengan kriteria inklusi jumlah bakteri dalam 1 cawan adalah 30-300 koloni.

\section{Uji Escherichia coli (SNI 2332.1:2015)}

Untuk mengetahui sampel siomay tersebut mengandung $E$. coli maka perlu di identifikasi menggunakan media EMB (Eosin Methylen Blue Agar). Pada media EMB dapat digunakan untuk isolasi dan differensiasi bakteri enterik atau Coliform. Pengujian E. coli dapat dilakukan dengan menggunakan hasil pengenceran sampel siomay dengan media pengencer (BFP), LTB, EMB sebanyak 9 gram, media E.C. Broth sebanyak 9,25 gram. kemudian inokulasikan hasil dari setiap tabung LTB yang positif ke tabung-tabung E.C. Broth yang berisi tabung durham dengan menggunakan jarum ose. Selanjutnya inkubasi E.C. Broth dalam waterbath selama 48 jam pada suhu $45^{\circ} \mathrm{C}$. jika tabung E.C. Broth 
positif maka ditandai dengan kekeruhan dan gas dalam tabung durham. Selanjutnya dilakukan uji penegasan E. coli yaitu dari tabung-tabung E.C. Broth yang positif dengan menggunakan jarum ose, kemudian gores ke media EMB agar. Inkubasi selama 18-24 jam pada suhu $35^{\circ} \mathrm{C}$, tahap selanjutnya koloni E.coli terduga memberikan ciri khas yaitu hitam dibagian tengah, ungu/pink datar (BSN, 2015).

\section{Analisis Data}

Analisis data dilakukan secara deskriptif dan disajikan dalam bentuk tabel untuk menjelaskan banyaknya koloni bakteri yang diperoleh dari jajanan siomay, serta hasil identifikasi bakteri Escherichia coli pada media EMB.

\section{HASIL DAN PEMBAHASAN}

Tabel 1. Hasil pengujian Angka Lempeng Total siomay ikan

\begin{tabular}{cccc}
\hline Sampe & (koloni/gram) & SNI Siomay & Keterangan \\
\hline A & $3,50 \times 10_{3}$ & $5 \times 10_{4}$ & MS \\
B & $3,00 \times 10_{3}$ & $5 \times 10_{4}$ & MS \\
C & $6,67 \times 10_{3}$ & $5 \times 10_{4}$ & MS \\
D & $8,00 \times 10_{3}$ & $5 \times 10_{4}$ & MS \\
\hline
\end{tabular}

Keterangan: ALT : Angka Lempeng Total

MS : Memenuhi Syarat

TMS : Tidak memenuhi syarat

Tabel 2. Identifikasi bakteri berdasarkan warna koloni yang dihasilkan pada setiap sampel

\begin{tabular}{cc}
\hline Sampel & Warna koloni pada media EMB \\
\hline A. & Ungu, pink, hitam pada bagian tengah, tanpa hijau metalik \\
B. & - \\
C. & Ungu, pink, hitam pada bagian tengah, tanpa hijau metalik \\
D. & Ungu, pink, hitam pada bagian tengah, tanpa hijau metalik \\
\hline
\end{tabular}

Dari Tabel 1 diketahui bahwa semua sampel menunjukkan hasil memenuhi syarat yang ditunjukkan dengan jumlah koloni pada keempat sampel tersebut baru pada kisaran 30-300. Berdasarkan tabel 1 Sampel $D$ merupakan sampel dengan jumlah koloni terbanyak sebesar $8,00 \times 103$ CFU/gr berdasarkan SNI 7756:2013 menyatakan bahwa siomay memiiki batas maksimun cemaran bakteri sebesar $5 \times 10_{4}$ sehingga pada penelitian ini, dari semua sampel siomay dapat dinyatakan layak dikonsumsi karena jumlah bakteri tidak melebihi ambang batas. Tingginya nilai Angka Lempeng Total (ALT) ini diduga karena proses pembuatan siomay yang diolah sendiri oleh pedagang tidak higienis, mulai dari peralatan masak yang kotor, air yang digunakan untuk pencucian bahan, air yang digunakan pada proses pemasakan telah tercemar dan tempat penjualan yang berlokasi di pinggir jalan.

Pada penelitian Tangahu (2014) melakukan penelitian pada 3 sampel siomay di Kota Gorontalo, hasil yang diperoleh bahwa 3 sampel tersebut telah tercemar oleh bakteri tetapi masih layak konsumsi karena jumlah koloni tidak melebihi ambang batas dengan total tiap sampel adalah sampel $A 3 \times$ $10{ }_{3} \mathrm{CFU} / \mathrm{g}$, sampel B $1,7 \times 10_{2} \mathrm{CFU} / \mathrm{g}$, dan sampel C 4 $x 10_{3} \mathrm{CFU} / \mathrm{g}$, dengan hasil tersebut bahwa ke-3 sampel siomay masih layak dikonsumsi.

Penelitian yang dilakukan oleh Gerry (2011) dengan sampel batagor, siomay, burger, pisang goreng, dan tempura. Hasil dari penelitian diperoleh siomay merupakan kontaminasi tertinggi dari semua sampel yang dilakukan sebesar 7,9 x 105 CFU/gram 
sehingga dapat disimpulkan bahwa sampel siomay telah melebihi ambang batas artinya siomay tidak layak dikonsumsi

Dampak negatif bila mengkonsumsi siomay yang mengandung cemaran mikroba dengan koloni bakteri dalam jumlah yang banyak akan mengakibatkan penyakit bawaan makanan atau dikenal dengan foodborne disease merupakan penyakit yang disebabkan oleh infeksi makanan yang mengandung mikroorganisme. Salah satu penyakit yang dapat ditimbulkan oleh makanan yang terkontaminasi yaitu infeksi saluran nafas dan infeksi saluran cerna, kemudian infeksi lainnya seperti infeksi saluran kemih, kulit bahkan infeksi sistemik.

Berdasarkan Tabel 2 hasil identifikasi bakteri diketahui bahwa sampel $A, C$ dan $D$ terdapat bakteri coliform seperti $E$. coli. Adanya bakteri disebabkan oleh penggunaan bahan-bahan yang tidak segar, peralatan yang tidak bersih, air yang di gunakan sudah tercemar, lokasi penjamahan yang tidak memungkinkan (kotor) dan sanitasi pekerja yang kurang baik. Sedangkan untuk perlakuan B tidak terdapat bakteri. Untuk siomay yang tidak terdapat bakteri, diduga bakteri mengalami kematian pada saat proses pemanasan atau proses pembuatan siomay dan penggunaan air bersih (tidak tercemar bakteri) dengan sanitasi yang baik dari para penjual. Seperti diketahui bakteri coliform seperti E. coli dapat tahan berbulan-bulan pada tanah dan didalam air, tetapi dapat mati dengan pemanasan pada suhu $60^{\circ} \mathrm{C}$ atau lebih selama 15 menit. Selain itu penggunaan wadah atau tempat yang telah dibersihkan terlebih dahulu dan siomay yang dimasak dahulu dalam keadaan panas juga dapat menghindari terjadinya kontaminasi bakteri E. coli.

Beberapa penyakit yang sering timbul akibat bakteri $E$. coli adalah penyakit diare, bakteri $E$. coli yang menyebakan diare sangat sering ditemukan diseluruh dunia. Bakteri ini diklasifikasikan oleh ciri khas sifat-sifat virulensinya dan setiap grup menimbulkan penyakit melalui mekanisme yang berbeda seperti yang sudah diutarakan. Gejalanya yaitu diare yang merupakan buang air besar yang encer dangan frekuensi $4 x$ atau lebih dalam sehari, kadang disertai muntah, badan lesu atau lemah, panas, tidak nafsu makan, bahkan darah dan lender dalam kotoran. Diare menyebabkan kehilangan cairan dan elektrolit sehingga anak menjadi rewel atau tejadi gangguan irama jantung maupun pendarahan otak (Arini et al., 2017).

\section{KESIMPULAN}

1. Terdapat cemaran mikroba pada jajanan anak sekolah yang dijajakan di beberapa SD Negeri di Kota Kendari, dimana dari 4 sampel siomay yang telah di uji diperoleh 3 sampel siomay yang tercemar bakteri $E$. coli yaitu sampel $\mathrm{A}(+), \mathrm{C}(+)$ dan $D(+)$ Positif tercemar bakteri E. coli dan 1 sampel siomay tidak tercemar oleh bakteri $E$. coli yaitu sampel B (-).

2. Dari 4 sampel siomay yang telah diuji ALT menggunakan media PCA diperoleh koloni bakteri dengan nilai ALT yang berbeda-beda yaitu A) $\left.\left.3,50 \times 10{ }_{3} \mathrm{CFU} / \mathrm{gr}, \mathrm{B}\right) 3,00 \times 102 \mathrm{CFU} / \mathrm{gr}, \mathrm{C}\right)$ $6,67 \times 10_{3} \mathrm{CFU} / \mathrm{gr}$ dan sampel D) $8,00 \times 10_{3}$ CFU/gr dan masih memenuhi standar SNI yang ditetapkan serta masih layak dikonsumsi.

\section{DAFTAR PUSTAKA}

Apriliana. D. 2007. Keamanan mikrobiologis produk jajanan kali lima di lingkungan Sekolah Dasar kecamatan Wonosari, kabupaten Gunungkidul [Skripsi] Yogyakarta: Universitas Gajah Mada

Arini D. L. D. dan Wulandari R. M. Analisis cemaran bakteri pada saus siomai dari pedagang keliling depan sekolah di daerah surakarta berdasarkan teknik penetapan angka lempeng total semarang: universitas pgri semarang; 2017

Badan Pengawas Obat dan Makanan (BPOM) RI. Pengujian Mikrobiologi Pangan. Info POM. Maret 2008; 9 (2): 1-12.

Badan Pengawas Obat dan Makanan RI. Pedoman Kriteria Cemaran pada Pangan Siap Saji dan Pangan Industri Rumah Tangga. 2012. http://www.pom.go.id/ppid/2016/kelengkapan/ laptah2015. pdf [diakses pada 29 April 2019]

Badan Pusat Statistik (BPS). 2016. Gambaran Umum 
Wilayah Kecamatan. Badan Pusat Statistik. Jakarta

Badan Standarisasi Nasional. 2013. Pengolahan, Persyaratan Serta Mutu Siomay Ikan., No SNI 7756. Jakarta

Badan Standarisasi Nasional (BSN), 2006. tentang Cara Uji Mikrobilologi-Bagian 3: Penentuan Angka Lempeng Total (ALT) Pada Produk Perikanan, SNI 01-2332.3.

Fitriyani $A$, dan Maryanto $H$. Identifikasi bakteri Salmonella sp dan Escherichia coli pada bumbu gado-gado siomay dan cilok di sekitar kampus Universitas Muhammadiyah Purwokerto [Skripsi] purwokerto: Universitas Muhammadiyah Purwakarta; 2014.

Hersiani. 2018. Analisis Kelayakan Usaha Siomay Ikan Berbasis Home Industry Di jalan Laute Kelurahan Mandonga Kecamatan Mandonga [Skripsi] Kendari: Universitas Halu Oleo.

Jawetz E. Medical Mikrobiology 24th ed. USA: Mc Graw hill, 2009. 223-36P

Mahon C, Lehman D, Manuselis G. Texbook of diagnostic microbiologi 4th ed. USA: Saunders Elsevier, 2015. 420-853P

Menteri Dalam Negeri. 2015. Daftar Luas 17 Kabupaten/Kota Di Provinsi Sulawesi Tenggara. Informasipedia. Jakarta.

Menteri kesehatan RI. Keputusan menteri kesehatan RI nomor 942/KEMENKES/SK/VII/2003 tentang pedoman persyaratan hygiene sanitasi makanan jajanan. Jakarta: Menteri Kesehatan RI. 2006. http://dinkes.surabaya.go.id [diakses pada 25 juni 2019]

Muthohar, dan Setyanova. 2004. Produksi pengolahan Siomai Ikan Berdasarkan SNI. Penebar Swadaya. Jakarta.

Pandit, S. 2008. Optimalkan Distribusi Hasil Perikanan. Bali Post. Bali.

Poernomo, H.S. 2002. Teknologi Pengolahan Ikan. Departemen Kelautan dan Perikanan. Pusat Pendidikan dan Pelatihan Perikanan.
Romadhon Z. 2016. Identifikasi Bakteri Escherichia Coli dan Salmonella Sp Pada Siomay Yang Dijual Di Kantin Sd Negeri Di Kelurahan Pisangan, Cirendeu, Dan Cempaka Putih [Skripsi] Jakarta: Uin Syarif Hidayatullah.

Safriana. 2012. Perilaku memilih jajanan pada siswa sekolah dasar di SD negeri garot kecamatan darul imarah kabupaten aceh besar tahun 2012 [Skripsi] Jakarta: Universitas Indonesia

Sari M. Uji bakteriologis dan resistensi antibiotik terhadap bakteri Escherihia coli dan Shigella sp pada makanan gado-gado di kantin UIN Syarif hidayatullah Jakarta [Skripsi] Tangerang Selatan: Universitas Islam Negeri Jakarta; 2015.

Siswono. 2003. Ikan Air Tawar Kaya Protein dan Vitamin.Gizi Net. Jakarta.

Sofiana E. 2012. Hubungan higienis dan sanitasi dengan kontaminasi Escherichia coli pada jajanan di Sekolah Dasar Kecamatan Tapos Depok tahun 2012 [Skripsi] Jakarta: Universitas Indonesia

Stardar nasional indonesia SNI 7388. Batas maksimum cemaran mikroba dalam pangan: Kemenkes Rl; 2009.

Suhartini dan Hidayat. 2005. Olahan Ikan Segar. Penerbit Trubus Agri Sarana. Surabaya.

Surdjana IM. 2013 Kejadian luar biasa keracunan makanan. Jurnal Skala Husada. No.10 (2) hal: 144-48.

Wijaya, A. (2011). Uji Cemaran Bakteri dan Identifikasi Escherichia Coli pada Siomay yang Dijual Dibeberapa Tempat Dikota Kendari. Akademi Analis Kesehatan Binahusada Kendari.

Yersi. 2014, Uji kuantitatif cemaran bakteri pada makaan siomay di kota gorontalo [Skripsi] Gorontalo: Universitas Gorontalo.

Yunus R., Mongan R., Rosnani 2017 tentang cemaran bakteri gram negatif pada jajanan siomay di kota kendari, jurnal Medical Laboratory Technology Journal Vol:3(1), Hal: 87-92 